\title{
Microbial Transformation of (-)-Alloisolongifolene
}

\author{
NAIK T. KHAN ${ }^{1}$, MUHAMMAD ATIF ${ }^{1}$ and AMAL AL-ABOUDI ${ }^{2 *}$ \\ ${ }^{1} \mathrm{H}$. E. J. Research Institute of Chemistry, International Center for Chemical \\ and Biological Sciences, University of Karachi, Karachi-75270, Pakistan. \\ ${ }^{2}$ Department of Chemistry, The University of Jordan, Amman11942, Jordan. \\ *Corresponding author E-mail: amal001 @ hotmail.com \\ http://dx.doi.org/10.13005/ojc/300304
}

(Received: June 03, 2014; Accepted: August 09, 2014)

\begin{abstract}
(-)-Alloisolongifolene (1) is a structural analogue of the naturally occurring longifolene. The microbial transformation of (-)-alloisolongifolene (1) by Cunninghamella elegans afforded two new metabolites, 3a-hydroxyalloisolongifolol (2) and 13-hydroxyalloisolongifolol (3). The structures of the metabolites were deduced on the basis of their spectral data, including $1 \mathrm{D}$ and 2D NMR, IR and HREIMS.
\end{abstract}

Key words: (-)-Alloisolongifolene; Microbial Transformation; Cunninghamella elegans; 3a-Hydroxyalloisolongifolol; 13-Hydroxyalloisolongifolol.

\section{INTRODUCTION}

Microbial transformation of terpenes has been an attractive method to produce new metabolites with enhanced biological activity ${ }^{1}$. Insertion of a hydroxyl group in one step, with high regio- and stereo-selectivity, at an inactive terpenoidal skeleton by microbial transformation remains unmatched by chemical means ${ }^{2}$. Hydroxylation of terpenes is of importance to the flavor and fragrance industry in the search for new production methods and new compounds ${ }^{3}$. A large number of sesquiterpenes with a bridged tricyclic skeleton have been isolated from plants and fungi ${ }^{4}$, some of them have exhibited interesting biological properties ${ }^{5}$. However, only a few reports about their fungal transformation have appeared ${ }^{6}$. Recently, biotransformation of various bridged sesquiterpenes has been described by Choudhary et al ${ }^{5,7,8}$, who reported regio- and stereoselective hydroxylation of (+)-cycloisolongifol-5b-ol , (-)-isolongifolol and (+)-isolongifolene-4-one by different fungi species.

(-)-Alloisolongifolene (1), a bridged tricyclic sesquiterpene, produced by acid-catalyzed isomerization of the naturally occurring longifolene 9,10 .

Biotransformation of 1 has been reported by using enzymes from chicory roots (Cichorium 
intybus) where the hydroxylation took place at an isopropylidene group at the allylic position ${ }^{11}$.

In the present study, we report that the microbial transformation of (-)-alloisolongifolene (1) using Cunninghamella elegans afforded two new hydroxylated metabolites (2 and 3 ).

\section{MATERIAL AND METHODS}

\section{General experimental procedures}

IR Spectra were recorded in $\mathrm{CHCl}_{3}$ on an FTIR-8900 spectrophotometer. Optical rotations were measured on a JASCO DIP-360 digital polarimeter. UV Spectra were recorded in $\mathrm{CHCl}_{3}$ solution on a Hitachi U-3200 spectrophotometer. The ${ }^{1} \mathrm{H}$ and ${ }^{13} \mathrm{C}$ NMR spectra were recorded in $\mathrm{CDCl}_{3}$ solution on a Bruker Avance-400 NMR at 400 and $100 \mathrm{MHz}$, respectively ( $d$ ppm, $J$ in $\mathrm{Hz}$ ). The $\mathrm{El}$ and HREI MS were recorded on JEOL JMS $600 \mathrm{H}$ mass spectrometer. TLC was performed using precoated plates (Silica gel 60, $\mathrm{PF}_{254}, 0.2 \mathrm{~mm}$, Merck). Compound 1 was purchased from Fluka.

\section{Organism and media}

Microbial culture, Cunninghamella elegans (NRRL 1392), was obtained from Northern Regional Research Laboratories (NRRL) and maintained on SDA and stored at $4{ }^{\circ} \mathrm{C}$ prior to use. The fermentation medium for Cunninghamella elegans (NRRL 1392), was prepared by dissolving the following ingredients in distilled water $(3.0 \mathrm{~L})$ : glucose $(30.0 \mathrm{~g})$, glycerol $(30.0 \mathrm{~mL})$, peptone $(15.0 \mathrm{~g})$, yeast extract $(15.0 \mathrm{~g})$, $\mathrm{KH}_{2} \mathrm{PO}_{4}(15.0 \mathrm{~g})$, and $\mathrm{NaCl}(15.0 \mathrm{~g})$.

\section{General fermentation and extraction procedure}

The fermentation media thus obtained was distributed among 30 flasks of $250 \mathrm{~mL}$ capacity (100 $\mathrm{mL}$ each) and autoclaved. The fermentation was carried out according to a standard stage II protocol 12, 13. Compound 1 (600 mg) was dissolved in 15 $\mathrm{mL}$ acetone and the solution was evenly distributed among the 30 flasks (20 mg/ $0.5 \mathrm{~mL}$ in each flask) containing 24 h culture of Cunninghamella elegans together with control flasks. Fermentation continued further for an additional 3 days on a rotatory shaker (200 rpm) at $29^{\circ} \mathrm{C}$. During the fermentation, aliquots from flasks were taken daily and analyzed by TLC in order to determine the degree of transformation of the substrate. One control flask, without biomass (for checking substrate stability), and one flask without exogenous substrate (for checking endogenous metabolite) were used. The culture media and mycelium were separated by filtration. The mycelium was washed with $\mathrm{CH}_{2} \mathrm{Cl}_{2}(1.0 \mathrm{~L})$ and the filtrate was extracted with $\mathrm{CH}_{2} \mathrm{Cl}_{2}$ (3' $3 \mathrm{~L}$ ). The combined organic extracts was washed with brine, dried over anhydrous $\mathrm{Na}_{2} \mathrm{SO}_{4}$ and then evaporated under reduced pressure to yield a crude brown gum ( $2.6 \mathrm{~g}$ ). Control flasks were also harvested and their contents tested by TLC to detect any biotransformed products. The crude residue $(2.6 \mathrm{~g})$ was subjected to column chromatography. Elution with petroleum ether and EtOAc yielded compounds 2 and 3 in $4.2 \%$, and $2.8 \%$ yields, respectively.

3a-Hydroxyalloisolongifolol (2) was obtained as an amorphous material. [a] ${ }^{25}$ : $+68(c=0.4$, $\left.\mathrm{CHCl}_{3}\right)$. UV $\left(\mathrm{CHCl}_{3}\right): \lambda_{\text {max }}(\log \in)=202 \mathrm{~nm}$ (1.8). IR $\left(\mathrm{CHCl}_{3}\right): v_{\max }=3419,2992 \mathrm{~cm}^{-1}$. ${ }^{1} \mathrm{H} \mathrm{NMR}\left(\mathrm{CDCl}_{3}\right.$, $400 \mathrm{MHz})$ : see Table $1 .{ }^{13} \mathrm{C} \mathrm{NMR}\left(\mathrm{CDCl}_{3}, 100 \mathrm{MHz}\right)$ : see Table 2. MS (El, $70 \mathrm{eV}): m / z(\%): 238(7)\left[\mathrm{M}^{+}\right]$, 220 (14), 206 (6), 166 (38), 146 (28), 120 (100), 78 (74), 55 (28). MS (HREI): $m / z=238.1084\left(\mathrm{C}_{15} \mathrm{H}_{26} \mathrm{O}_{2}\right.$, calcd 238.1093).

13-Hydroxyalloisolongifolol (3) was obtained as an amorphous material. $[\alpha]^{25}:+116(c=0.5$, $\left.\mathrm{CHCl}_{3}\right)$. UV $\left(\mathrm{CHCl}_{3}\right): \lambda_{\max }(\log \in)=203 \mathrm{~nm}(2.2)$. IR $\left(\mathrm{CHCl}_{3}\right): v_{\max }=3401,2986 \mathrm{~cm}^{-1} .{ }^{1} \mathrm{H} \mathrm{NMR}\left(\mathrm{CDCl}_{3}, 400\right.$ $\mathrm{MHz})$ : see Table $1 .{ }^{13} \mathrm{C}$ NMR $\left(\mathrm{CDCl}_{3}, 100 \mathrm{MHz}\right)$ : see Table 2. MS (El, $70 \mathrm{eV}): m / z(\%)=238(16)\left[\mathrm{M}^{+}\right]$, 220 (31), 208 (26), 166 (26), 152 (16), 120 (100), 78 (28), 55 (47). MS (HREI): $m / z=238.1074\left(\mathrm{C}_{15} \mathrm{H}_{26} \mathrm{O}_{2}\right.$, calcd 238.1086).

\section{RESULTS AND DISCUSSION}

To investigate the capacity of Cunninghamella elegans to metabolise compound 1 , a small-scale experiment was conducted. TLC of the crude chloroform extract indicated the presence of two new more polar metabolites. Subsequently, a large-scale fermentation was carried out to produce sufficient quantities of these metabolites for structure elucidation. Biotransformation of compound 1 with Cunninghamella elegans for 3 days yielded the new metabolites 2 and 3 (Scheme-1).

The HREIMS of compound 2 exhibited $\mathrm{M}^{+}$at 
$\mathrm{m} / \mathrm{z} 238.1084$, corresponding to the formula $\mathrm{C}_{15} \mathrm{H}_{26} \mathrm{O}_{2}$ (calcd 238.1093), which is 34 a.m.u. higher than the substrate 1. The IR spectrum of compound 2 showed absorption at $3524 \mathrm{~cm}^{-1}$ indicating the presence of hydroxyl groups. The ${ }^{1} \mathrm{H}$ NMR spectrum (Table 1) of compound 2 was quite different from the parent compound 1. The olefinic proton signals at $d 4.73$ and 4.63 of 1 were absent, while three new additional

Table 1: ${ }^{1} \mathrm{H}$ NMR chemical shift data of the compounds 1-3

\begin{tabular}{|c|c|c|c|}
\hline Position & $1 \delta_{H}(J$ in $\mathrm{Hz})$ & $2 \delta_{H}(J$ in $H z)$ & $3 \delta_{H}(J$ in $\mathrm{Hz})$ \\
\hline 1 & $1.52, \mathrm{~m}$ & $1.80, \mathrm{~m}$ & $2.05, \mathrm{~m}$ \\
\hline 2 & - & - & - \\
\hline 3 & $1.44 ; 1.12, \mathrm{~m}$ & $3.57(\mathrm{dd}, J=15.1,6.0 \mathrm{~Hz})$ & $1.30 ; 1.18, \mathrm{~m}$ \\
\hline 4 & $1.57 ; 1.49, \mathrm{~m}$ & $1.67 ; 1.04, \mathrm{~m}$ & $1.54 ; 1.44, \mathrm{~m}$ \\
\hline 5 & $1.60 ; 1.40, \mathrm{~m}$ & $1.62 ; 1.12, \mathrm{~m}$ & $1.69 ; 1.37, \mathrm{~m}$ \\
\hline 6 & - & - & - \\
\hline 7 & $1.53 ; 1.35, \mathrm{~m}$ & $1.58 ; 0.82, \mathrm{~m}$ & $1.50 ; 1.35, \mathrm{~m}$ \\
\hline 8 & - & - & - \\
\hline 9 & $1.55 ; 1.47, \mathrm{~m}$ & $1.59 ; 1.25, \mathrm{~m}$ & $1.50 ; 1.44, \mathrm{~m}$ \\
\hline 10 & $1.59 ; 1.22, \mathrm{~m}$ & $1.56 ; 0.97, \mathrm{~m}$ & $1.48 ; 1.31, \mathrm{~m}$ \\
\hline 11 & $0.76, \mathrm{~s}$ & $0.86, \mathrm{~s}$ & $0.80, \mathrm{~s}$ \\
\hline 12 & $0.87, \mathrm{~s}$ & $0.94, \mathrm{~s}$ & $0.87, \mathrm{~s}$ \\
\hline 13 & - & $1.76, \mathrm{~m}$ & - \\
\hline 14 & $4.73 ; 4.63$ (br s) & $\begin{array}{l}3.60(\mathrm{dd}, J=12.2,6.0 \mathrm{~Hz}) \text {; } \\
3.38(\mathrm{t}, J=12.2, \mathrm{~Hz})\end{array}$ & $\begin{array}{l}4.03 ; 3.26 \\
(d, J=10.7 \mathrm{~Hz})\end{array}$ \\
\hline 15 & $1.67, \mathrm{~s}$ & $1.01(\mathrm{~d}, J=6.8 \mathrm{~Hz})$ & $1.09, \mathrm{~s}$ \\
\hline
\end{tabular}

Table 2: ${ }^{13} \mathrm{C}$ NMR Chemical shift data of the compounds 1-3

\begin{tabular}{llll}
\hline Position & $1 \boldsymbol{d}_{\mathrm{c}}$ & $\mathbf{2} \boldsymbol{d}_{\mathrm{c}}$ & $3 \boldsymbol{d}_{\mathrm{c}}$ \\
\hline 1 & $51.8, \mathrm{~d}$ & $41.8, \mathrm{~d}$ & $50.9, \mathrm{~d}$ \\
2 & $46.8, \mathrm{~s}$ & $53.2, \mathrm{~s}$ & $46.7, \mathrm{~s}$ \\
3 & $38.8, \mathrm{t}$ & $72.1, \mathrm{~d}$ & $38.5, \mathrm{t}$ \\
4 & $20.7, \mathrm{t}$ & $47.8, \mathrm{t}$ & $22.2, \mathrm{t}$ \\
5 & $44.0, \mathrm{t}$ & $39.0, \mathrm{t}$ & $44.1, \mathrm{t}$ \\
6 & $49.7, \mathrm{~s}$ & $46.5, \mathrm{~s}$ & $51.9, \mathrm{~s}$ \\
7 & $22.0, \mathrm{t}$ & $19.8, \mathrm{t}$ & $21.6, \mathrm{t}$ \\
8 & $47.9, \mathrm{~s}$ & $44.2, \mathrm{~s}$ & $46.9, \mathrm{~s}$ \\
9 & $32.5, \mathrm{t}$ & $29.2, \mathrm{t}$ & $35.2, \mathrm{t}$ \\
10 & $36.5, \mathrm{t}$ & $23.9, \mathrm{t}$ & $36.2, \mathrm{t}$ \\
11 & $19.8, \mathrm{q}$ & $12.5, \mathrm{q}$ & $15.6, \mathrm{q}$ \\
12 & $15.4, \mathrm{q}$ & $15.4, \mathrm{q}$ & $22.9, \mathrm{q}$ \\
13 & $152.5, \mathrm{~s}$ & $47.5, \mathrm{~d}$ & $83.8, \mathrm{~s}$ \\
14 & $109.4, \mathrm{t}$ & $66.5, \mathrm{t}$ & $71.6, \mathrm{t}$ \\
15 & $20.5, \mathrm{q}$ & $15.9, \mathrm{q}$ & $20.1, \mathrm{q}$ \\
\hline
\end{tabular}

Carbon multiplicities were determined by DEPT experiment; $\mathrm{s}=$ quaternary, $\mathrm{d}=$ methine, $\mathrm{t}=$ methylene, $\mathrm{q}=$ methyl carbons. signals appeared at $d 3.57\left(1 \mathrm{H}, \mathrm{dd}, J_{3 b, 4 a}=15.1 \mathrm{~Hz}\right.$, , $\left.J_{3 b, 4 b}=6.0 \mathrm{~Hz}\right), 3.60\left(1 \mathrm{H}, \mathrm{dd}, J_{14 a, 14 \mathrm{~b}}=12.2 \mathrm{~Hz}, J_{14,13}\right.$ $=6.0 \mathrm{~Hz})$ and $3.38(1 \mathrm{H}, \mathrm{t}, J=12.2 \mathrm{~Hz})$, assigned for $\mathrm{H}-3$ and the two vicinal protons attached to $\mathrm{C}-14$, respectively. The ${ }^{13} \mathrm{C}-\mathrm{NMR}$ and DEPT spectra of 2 (Table 2) confirmed anti-Markovnikove's hydration of the double bond. It showed the absence of the double bond signals, the presence of a $\mathrm{CH}$ at $d 47.5$ and a downfield $\mathrm{CH}_{2}$ at $d 66.5$, assigned to $\mathrm{C}-13$ and $\mathrm{C}-14$, respectively. The downfield $\mathrm{CH}$ signal at $d 72.1$, the absence of the methylene carbon at $d$ 38.8 and the downfield shifts of $\mathrm{C}-2$ and $\mathrm{C}-4$ signals (Table 2) indicated hydroxylation at C-3 of compound 2. COSY $45^{\circ}$ and HMBC experiments supported these assignments. COSY $45^{\circ}$ showed correlations between $\mathrm{H}-14$ ( $d 3.60,3.38$ ) and $\mathrm{H}-13$ (1.76), and $\mathrm{HMBC}$ showed correlations between $\mathrm{H}-14$ (d 3.60, 3.38) and C-15 (d 15.9), and C-13 (d 47.5). The position of the second $\mathrm{OH}$ group at $\mathrm{C}-3$ was confirmed by the HMBC correlations of $\mathrm{H}-3$ (d3.57) with C-12 ( $d$ 15.4), C-4 (d 47.8), and C-2 (d 53.2). The stereochemistry of the $\mathrm{C}-3$ hydroxyl group was determined as $a$ on the basis of NOESY correlations between $\mathrm{H}-3$ ( $d$ 3.57) and each of $\mathrm{H}-1 \alpha(d 1.80)$, 


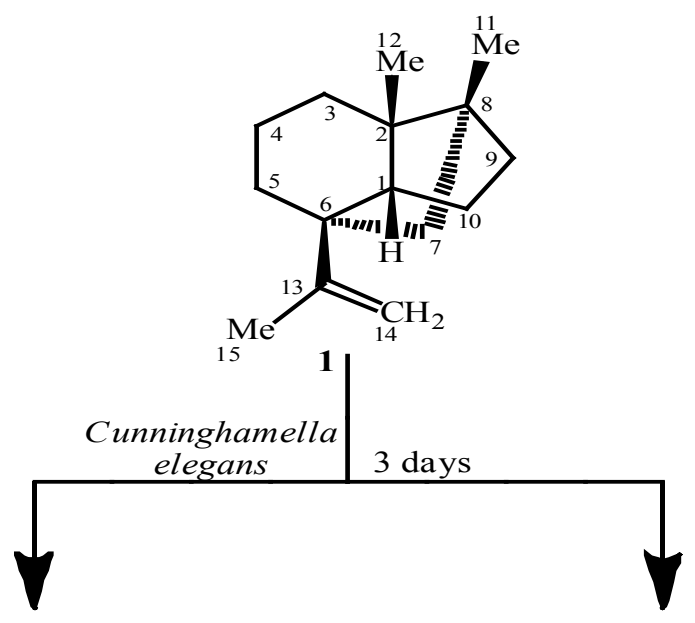

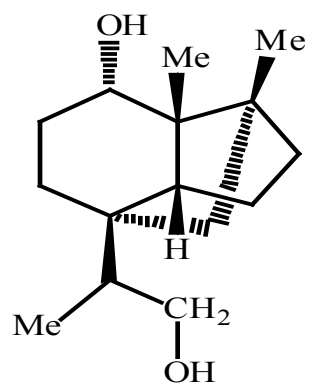

2

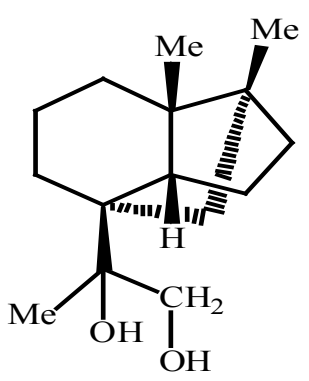

3

Scheme 1: Biotransformation of (-)-alloisolongifolene (1) with Cunninghamella elegans<smiles>CC=C(C)CC</smiles><smiles>CC(C)CCCCC(C)(C)C</smiles><smiles>C[C@@H]1O[C@H]1C</smiles>
Epoxide hydrolase<smiles>CC(C)[C@@H](C)O</smiles>

Scheme 2: Proposed intermediate for the formation of compound 2

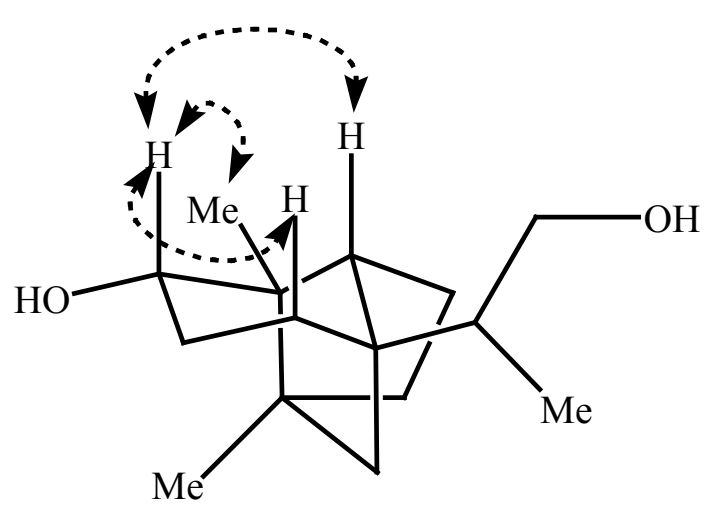

Fig. 1: Key NOESY correlations in compound 2
$\mathrm{H}-5 \mathrm{a}(d$ 1.62) and Me-12 $\alpha$ ( $d$ 0.94). The structure of the new metabolite 2 was thus established as 3-hydroxyalloisolongifolol.

The HREI MS of metabolite 3 showed the $\mathrm{M}^{+}$at $\mathrm{m} / \mathrm{z} 238.1074\left(\mathrm{C}_{15} \mathrm{H}_{26} \mathrm{O}_{2}\right.$, calcd 238.1086), similar to that of compound 2. The ${ }^{1} \mathrm{H}$ NMR spectrum (Table 1) showed $A B$ doublets at $d 4.03\left(J_{14 a, 14 b}=\right.$ $10.7 \mathrm{~Hz})$ and $3.26\left(J_{14 \mathrm{~b}, 14 \mathrm{a}}=10.7 \mathrm{~Hz}\right)$, indicating the hydroxylation of the $\mathrm{C}-13 / \mathrm{C}-14$ double-bond. The ${ }^{13} \mathrm{C}$ NMR spectrum (Table 2) of compound $\mathbf{3}$ was similar to that of compound 1 , except for the absence of the double bond and the appearance of additional downfield $\mathrm{OH}$ bearing signals at $d$ 
71.6 (C-14), and 83.8 (C-13). The dihydroxylation of the double bond was further confirmed by the HMBC correlations between Me-15 (d 1.09) and C-13 (d 83.8), C-14 (d 71.6), and C-6 (d 51.9). Based on the above mentioned spectral data, the structure of the new metabolite $\mathbf{3}$ was deduced as 13-hydroxyalloisolongifolol.

It has been reported that the filamentous fungus Cunninghamella elegans contains enzymes with activities similar to those found in mammals, some of which are P-450 mono-oxygenase and epoxide hydrolase ${ }^{14}$. So we think that compound 2 may have formed from anti hydrolysis of the corresponding epoxide as shown in scheme 2.

Cunninghamella elegans fungus was able to bio-catalyze the hydroxylation of the bridged sesquiterpenes, (-)-alloisolongifolene (1), in a regio and stereo-specific manner. It introduced a hydroxyl group at the 3a-position, and hydrate the double bond in an anti-Markovnikov's producing a new compound 3a-Hydroxyalloisolongifolol (2), in addition to oxidation of the double bond (C-13, C-14) to the corresponding diol to give the new compound 13-Hydroxyalloisolongifolol (3).

\section{ACKNOWLEDGEMENTS}

The authors acknowledge the Higher Education Commission, Islamabad, Pakistan for the financial support through Indigenous Ph. D. Fellowship Program, and acknowledge the assistance of Prof. Atta-ur-Rahman and Prof. Mohammad Iqbal Choudhary though out this work.

\section{REFERENCES}

1. Bhatti, H. N.; Zubair, M.; Rasool, N.; Hassan, Z.; Ahmad, V. U. Nat. Prod. Commun. 2009. 4(8), 1155-1168.

2. Rocha, B. A.; Pupo, M. T.; Antonucci, G. A.; Sampaio, S. V.; Paiva, R. M. V.; Said, S.; Gobbo-Neto, L.; Costa, F. B. J. Ind. Microbiol. Biotechnol. 2012, 39(11), 1719-1724.

3. Faber, K. Biotransformations in organic chemistry: A Textbook. 4th ed. Springer: Berlin, (2000).

4. Cohen, H.; Charrier, C.; Ricard, L.; Perreau, M. J. Nat. Prod. 1992, 55, 326-332.

5. Choudhary, M. I.; Musharraf, S. G.; Ahmad, N. S.; Anjum, S; Parvez, M.; Fun, H. K.; Attaur-Rahman. Bioorg. Med. Chem. 2005, 13(6), 1939-1944.

6. Aleu, J.; Hanson, J.; R.; Galán, R. H.; Collado, I. G. J. Nat. Prod. 1999, 62, 437-440.

7. Choudhary, M. I.; Kausar, W.; Siddiqui, Z. A.; Atta-ur-Rahman. Z. Naturforsch. 2006, 61b,
1035-1038.

8. Choudhary, M. I.; Musharraf, S. G.; Khan, M. T. H.; Abdelrahman, D.; Parvez, M.; Shaheen, F.; Atta-ur-Rahman. Helv. Chim. Acta 2003, 86(10), 3450-3460.

9. Shitole, H. R.; Pramod, V.; Nayak, U. R. Tetrahedron Lett. 1983, 24(23), 2411-2412.

10. Mota, J. S.; Souza, D. S.; Boone, C. V.; Cardoso, C.A. L.; Caramao, E. B. J. Essent. Oil Bear. Pls. 2013, 16(1), 11-16.

11. Kraker, D.; Schurink, M.; Franssen, M. C. R.; König, W. A.; Groot, A.; Bouwmeester, H. J. Tetrahedron 2003, 59(3),409-418.

12. Betts, R. E.; Walters, D. E.; Rosazza, J. P. J. Med. Chem. 1974, 17(6), 599-602.

13. Choudhary, M. I.; Nasir, M. Khan, S. N.; Atif, M.; Ali, R. A. Khalil, S. M.; Atta-ur-Rahman. Z. Naturforsch. 2007, 62b, 593 - 599.

14. Wackett, L. P.; Gibson, D. T. Biochem. J.1982, 205, 117-122. 